日植病報 $49: 593-599$ (1983)

Ann. Phytopath. Soc. Japan 49 : 593-599 (1983)

\title{
Radish Yellow Edge Virus, a Seed-borne Virus with Double-stranded RNA, of a Possible New Group
}

\author{
Tomohide Natsuaki*, Shuichi Yamashita**, Yoji DoI**, \\ Seiichi OKudA* and Michiaki TeranakA* \\ 夏秋知英*・山下修一**・土居養二**・奥田誠一*・寺中理明*：ダイコン葉縁黄化 \\ ウイルス一新グループの種子伝染性二本鎖 RNA ウイルス
}

\begin{abstract}
Radish yellow edge virus (RYEV) was purified from infected Japanese radish (Raphanus sativus L.) by $\mathrm{CsCl}$ equilibrium density gradient centrifugation. Virus particles banded with a buoyant density of about $1.37 \mathrm{~g} / \mathrm{cm}^{3}$ in $\mathrm{CsCl}$. Purified RYEV preparations showed UV absorption spectrum characteristic of a nucleoprotein with $A_{\max } / A_{\min }$ and $A_{260} / A_{280}$ ratios of about 1.10 and 1.39 , respectively. Proteins from purified RYEV preparations, electrophoresed in SDS-polyacrylamide gels, migrated as two species with mol. wt. of about 63,000 and 61,000. RYEV nucleic acid was judged to be double-stranded ribonucleic acid (dsRNA) from its resistance to RNase in high ionic strength conditions and from its reaction with an antiserum to poly (I) : poly (C). In polyacrylamide gel electrophoresis, RYEV dsRNA was fractionated into three major classes with mol. wt. of approximately $1.30,1.25,1.21 \times 10^{6}$ and two minor ones of $1.14,1.09 \times 10^{6}$. RYEV was not related serologically to turnip crinkle, turnip rosette, turnip mosaic and cucumber mosaic viruses which infect crucifers or to ten seed-borne viruses which resemble RYEV in particle morphology and biological aspects. It is highly likely that RYEV and several other seed-borne dsRNA viruses constitute a new group of plant viruses.
\end{abstract}

(Received March 28, 1983)

Key Words : radish yellow edge virus, seed-borne virus, double-stranded RNA.

\section{Introduction}

Radish yellow edge virus (RYEV), detected in Japanese radish (Raphanus sativus L.) is a seed-borne virus with small isometric particles about $30 \mathrm{~nm}$ in diameter ${ }^{17)}$. RYEVinfected seedlings usually show no symptoms but sometimes cause mild yellow edge of leaves. RYEV was transmitted through seed in high frequency but not by sap. Virus particles were observed only in cells of vascular bundles in thin sections. Nine seed-borne "temperate" viruses, including spinach temperate virus, carrot temperate virus etc., have been recognized in nine plant species from six families ${ }^{14,16,17,18)}$. They closely resemble RYEV in particle morphology, transmissibility and some other characteristics. Beet cryptic virus" and other "cryptic" viruses",7,10) also share

* Faculty of Agriculture, Utsunomiya University, Mine-machi, Utsunomiya, Tochigi 321, Japan 宇都宮大学農学部

** Faculty of Agriculture, University of Tokyo, Bunkyo-ku, Tokyo 113, Japan 東京大学農学部 
properties similar to those of RYEV.

This paper describes nucleic acid and some other properties of RYEV.

\section{Materials and Methods}

RYEV purification. RYEV was purified from infected Japanese radish cv. Minowase grown in sterilized soil. Frozen leaves were homogenized in $0.1 \mathrm{M}$ phosphate butter $(2 \mathrm{ml} / \mathrm{g}$ tissue) containing $0.1 \%$ thioglycolic acid ( $\mathrm{pH} 7.6)$. The homogenate was squeezed through two layers of cheese cloth, mixed with half volume of $1: 1$ chloroform and $\mathrm{n}$-butanol and stirred. The emulsion was centrifuged for $10 \mathrm{~min}$ at ca. $8,000 \times g$ and the supernatant centrifuged for $1.5 \mathrm{hr}$ at $123,400 \times \mathrm{g}$. After resuspending the pellets in $0.1 \mathrm{M}$ phosphate buffer and two further cycles of differential centrifugation, final preparation was subjected to $10-40 \%$ linear sucrose density gradient centrifugation for $2.5 \mathrm{hr}$ at $68,900 \times g$. Then the partially purified preparation was subjected to $35 \% \mathrm{w} / \mathrm{v} \mathrm{CsCl}$ equilibrium density gradient centrifugation for $20 \mathrm{hr}$ at $117,800 \times g$.

Analysis of the protein. Purified RYEV preparation and marker proteins, boiled for $5 \mathrm{~min}$ in $0.05 \mathrm{M}$ Tris $-\mathrm{HCl}(\mathrm{pH} 9)$ containing $2 \%$ sodium dodecyl sulfate (SDS) and 1\% 2-mercaptoethanol (2-MEC), were subjected to electrophoresis on $12.5 \%$ SDS-polyacrylamide slab gel at $40 \mathrm{~mA}$ for about $4.5 \mathrm{hr}$ and stained with Coomassie brilliant blue as described by Laemmli ${ }^{8}$.

Nucleic acid extraction and analysis. Purified or partially purified RYEV preparation were incubated with $1 \%$ SDS, $0.1 \%$ bentonite and $1 \% 2-\mathrm{MEC}$ in $0.01 \mathrm{M}$ sodium phosphate buffer ( $\mathrm{pH} 7.0$ ) containing $1 \mathrm{mM}$ sodium ethylenediaminetetraacetic acid (Na-EDTA) for $5 \mathrm{~min}$ at $50 \mathrm{C}$ and then extracted two times with $80 \%$ phenol containing $0.1 \%$ 8-hydroxyquinoline. The nucleic acid was precipitated from aqueous phase by adding 2 vol cold ethanol and stored at $-20 \mathrm{C}$. The double-stranded ribonucleic acids (dsRNA) of Penicillium chrysogenum virus ( $\mathrm{PcV}$, a fungal virus from strain IAM 7326) and rice dwarf virus (RDV, a member of plant reovirus) were prepared as described by Wood and Bozarth ${ }^{20)}$ and Reddy et al. ${ }^{19)}$ respectively.

Nucleic acids were analysed by electrophoresis in $5 \%$ polyacrylamide gel. The buffer used were Loening's $(0.04 \mathrm{M}$ Tris, $0.02 \mathrm{M}$ sodium acetate, $1 \mathrm{mM}$ Na-EDTA, $\mathrm{pH} 7.2)^{11)}$. Gels were stained with 'Stains all'1). For nucleic acid identification, after electrophoresis polyacrylamide gels were incubated with $50 \mu \mathrm{g} / \mathrm{ml}$ of ribonuclease (RNase) in either distilled water or $0.3 \mathrm{M} \mathrm{NaCl}$ as described by Morris and Dodds ${ }^{13}$.

Poly $(\boldsymbol{I}): \operatorname{poly}(\boldsymbol{C})$ antiserum. Antiserum to dsRNA was made against complex of synthetic polyinosinic: polycytidylic acid (poly (I): poly (C), Yamasa Co., Choshi, Japan) and methylated bovine serum albumin, and serological tests were done by two dimentional immunodiffusion as described by Francki and Jackson ${ }^{2}$. The sensitivity of nucleic acids to RNase and deoxyribonuclease (DNase) were tested by incubation of nucleic acids with $0.1 \mu \mathrm{g} / \mathrm{ml}$ of RNase in 2 or $0.1 \times \mathrm{SSC}$ buffer $(0.15 \mathrm{M} \mathrm{NaCl}, 0.015 \mathrm{M}$ sodium citrate, $\mathrm{pH} 7.0$ ) and with $1 \mu \mathrm{g} / \mathrm{ml}$ of DNase in $0.02 \mathrm{M}$ phosphate buffer containing $3 \mathrm{mM} \mathrm{MgCl}$. The samples, after incubated for $20 \mathrm{~min}$ at $30 \mathrm{C}$, were added $2 \mathrm{vol}$ cold ethanol and then subjected to immunodiffusion tests.

Serology. Antiserum to RYEV was obtained from a rabbit immunized with 
four intramuscular injections of purified virus preparation emulsified with Freund's complete adjuvant. Antisera for comparative serological tests were kindly supplied by Dr. R. Hull (turnip crinkle and turnip rosette viruses) and Dr. R. F. White (beet cryptic virus).

\section{Results}

\section{Properties of purified $R Y E V$ preparation}

RYEV formed one band at a density of about $1.37 \mathrm{~g} /$ $\mathrm{cm}^{3}$ (Fig. 1). The purified preparation (Fig. 2) showed an UV absorption spectrum characteristic of a nucleoprotein, with $\mathrm{A}_{\max } / \mathrm{A}_{\min }$ and $\mathrm{A}_{260} / \mathrm{A}_{280}$ ratios of about 1.10 and 1.39 respectively. The yield of virus was $1 \mathrm{mg}$ per $3 \mathrm{~kg}$ tissues, assuming a value of 5.0 for $A_{260}(1 \mathrm{mg} / \mathrm{ml})$.

\section{Protein}

When electrophoresed in SDS-polyacrylamide gels, proteins from RYEV particles migrated as two species, with estimated mol. wt. of about 63,000 and 61,000 (Fig. 3 A and $\mathrm{B}$ ).

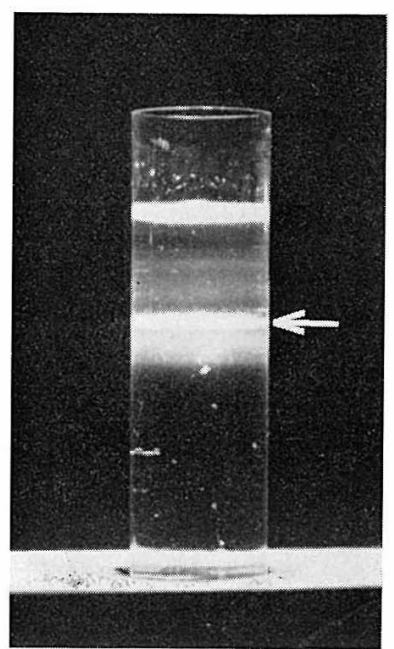

Fig. 1. A band (arrow) of RYEV particles(shown in Fig. 2) formed by $\mathrm{CsCl}$ equilibrium density gradient centrifugation.

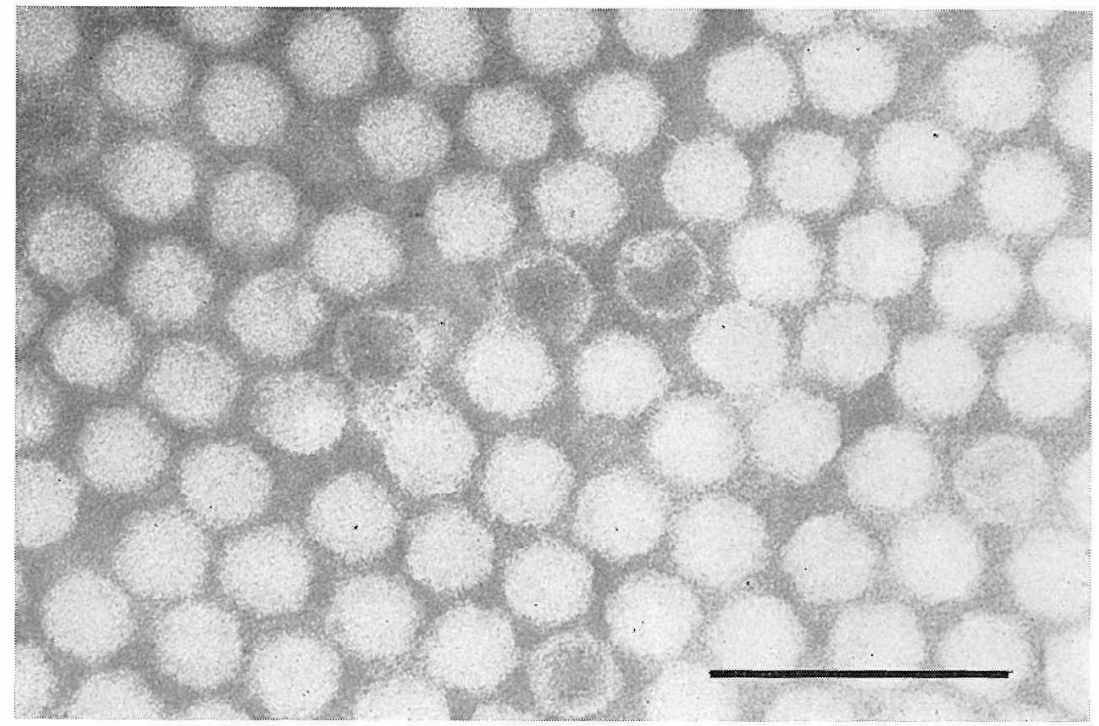

Fig. 2. Purified RYEV particles stained with $2 \%$ phosphotungstate $\mathrm{pH}$ 6. Bar represents $100 \mathrm{~nm}$.

\section{Nucleic acid}

The gels in which the preparation of RYEV nucleic acid was electrophoresed were incubated with RNase in either distilled water or $0.3 \mathrm{M} \mathrm{NaCl}$. Bands of RYEV nucleic acid were readily digested in distilled water but not in $0.3 \mathrm{M} \mathrm{NaCl}$. RYEV 

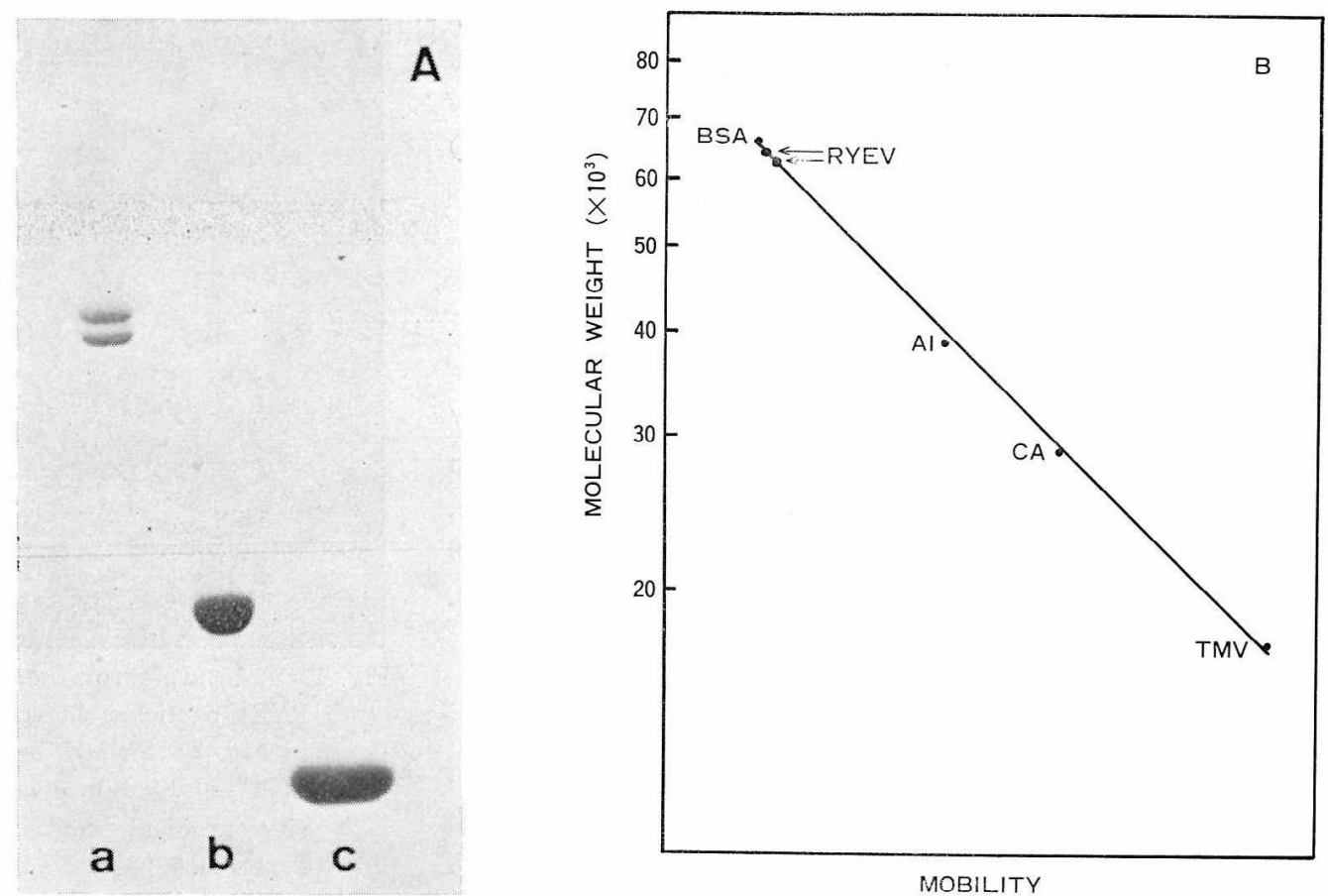

Fig. 3. A: Electrophoresis of RYEV protein in $12.5 \%$ SDS-polyacrylamide slab gel, (a) RYEV protein, (b) cucumber mosaic virus protein, (c) tobacco mosaic virus (TMV) protein.

B: Molecular weights of RYEV and marker proteins estimated from mobility in $12.5 \%$ SDS-polyacrylamide slab gel. Marker proteins used are; bovine serum albumin (BSA, MW 66,000), aldolase (Al, MW 39,000), carbonic anhydrase (CA, MW 28,800), and TMV protein (TMV, MW 17,500).

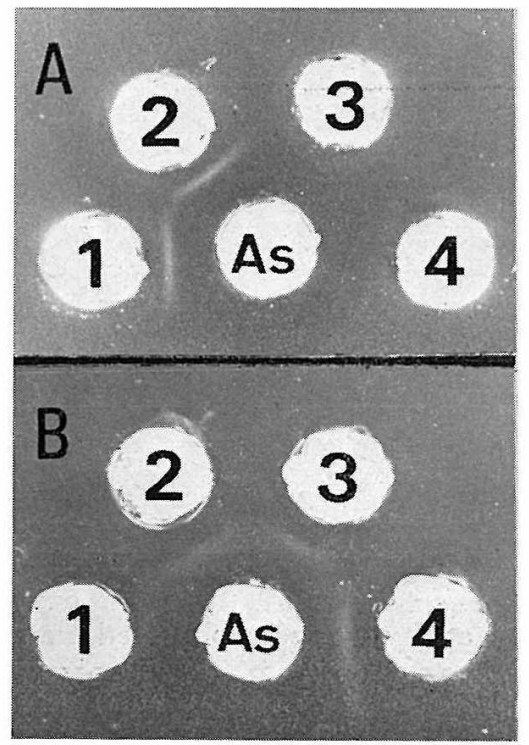

Fig. 4. Gel immunodiffusion test. A : well (As) contained poly (I): poly (C) antiserum, the rest contained PcV dsRNA (1), RYEV nucleic acid (2), total nucleic acid from healthy tobacco leaves (3), and cucumber mosaic virus single-stranded RNA (4), B: well (As) contained poly (I): poly (C) antiserum, the rest contained RYEV nucleic acid treated with RNase in $0.1 \times \mathrm{SSC}$ (1), treated with RNase in $2 \times \mathrm{SSC}$ (2), treated with DNase (3), and untreated (4). 
nucleic acid gave one band in two dimentional immunodiffusion tests against poly (I) : poly (C) antiserum (Fig. 4), reacting with $1 \mathrm{mg} / \mathrm{ml}$ of poly (I): poly (C) to a titer of 1 : 64. Precipitine lines were detected when RYEV nucleic acid was incubated with DNase or RNase in $2 \times$ SSC but not with RNase in 0.1 $\times$ SSC. The nucleic acid gave three major and two minor bands when electrophoresed. The apparent mol. wt. of RYEV nucleic acid segments, using RDV dsRNA as markers, were approximately $1.30,1.25,1.21 \times 10^{6}$ for majors and $1.14,1.09 \times 10^{6}$ for minors (Fig. 5). These results indicated that the nucleic acid of RYEV consists of dsRNAs. The determination of whether RYEV segmented dsRNAs are encapsidated in one particle or separate ones must await further studies.

\section{Serology}

In double diffusion tests, purified RYEV preparation didn't react with any antisera to turnip crinkle, turnip rosette and beet cryptic viruses. Antiserum to RYEV reacted specifically with the purified preparation to dillutions of $1 / 128$ but not with crude radish extract, turnip

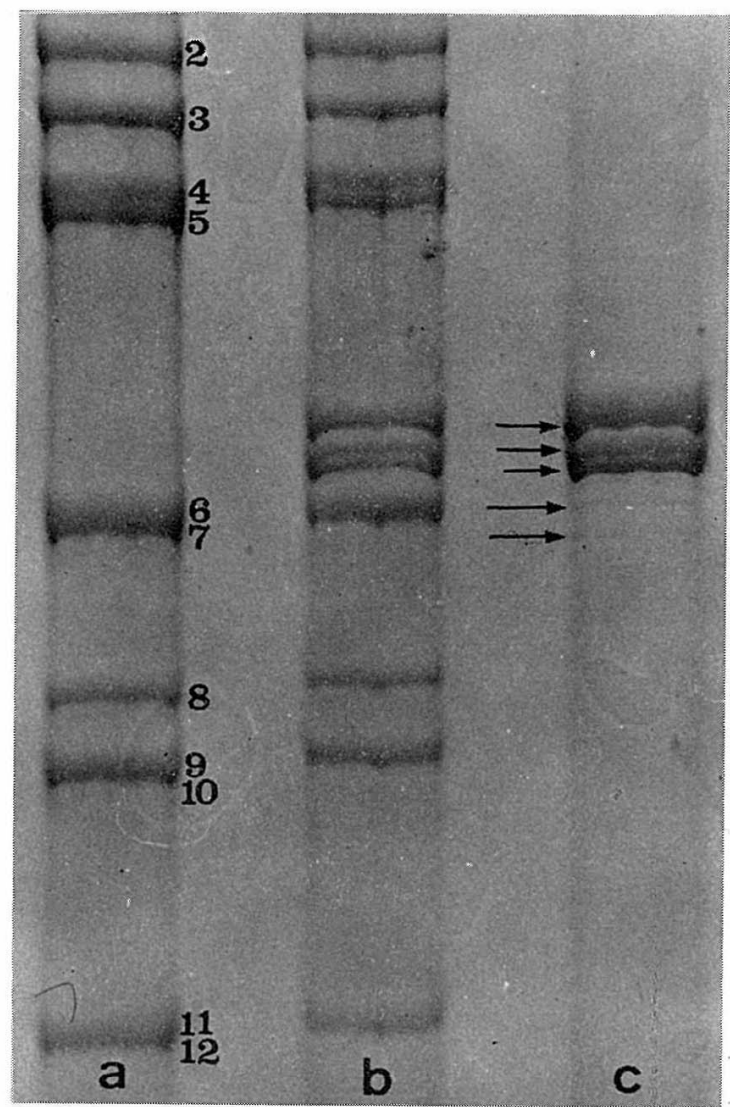

Fig. 5. Electrophoresis of RYEV ds RNA in $5 \%$ polyacrylamide slab gel : (a) RDV dsRNA as marker, MW $2.50 \times 10^{6}$ (2), $2.25 \times 10^{6}$ (3) $, 1.90 \times 10^{6}(4), 1.80 \times 10^{6}(5), 1.15 \times 10^{8}$ (6), $1.13 \times 10^{6}(7), 0.86 \times 10^{6}(8), 0.78 \times 10^{6}$ (9), $0.75 \times 10^{6}(10)$ and $0.52 \times 10^{6}(11,12)$, segment No. 1, MW $3.10 \times 10^{5}$, is not shown here; (b) RDV dsRNA and RYEV dsRNA ; (c) RYEV dsRNA, detected three major and two minor species (arrows). mosaic or cucumber mosaic viruses.

In immune electron microscopic observations, RYEV antiserum didn't react with seed-borne "temperate" viruses isolated from spinach (Spinacia oleracea), leaf beet (Beta vulgaris var. cicla), carrot (Daucus carota), garland chrysanthemum (Chrysanthemum coronarium), santosai (Brassica rapa var. amplexicaulis subvar. dentata), mibuna ( $B$. rapa var. laciniifolia), garden rhubarb (Rheum rhaponticum), alfalfa (Medicago sativa subsp. sativa) and white clover (Trifolium repens) ${ }^{14,16,17,18)}$.

\section{Discussion}

The data presented here and in the previous report ${ }^{17}$ show that RYEV has properties as follows; (1) high frequency (80-100\%) of seed transmission, (2) untransmissibility 
by mechanical inoculation, (3) isometric particles about $30 \mathrm{~nm}$ in diameter, (4) low concentration in infected plants which usually show no symptoms, (5) virus particles confined to vascular bundle cells, (6) sedimentation coefficient of $118 \mathrm{~S}$ and buoyant density of about $1.37 \mathrm{~g} / \mathrm{cm}^{3}$, (7) containing two polypeptides, and (8) the nucleic acid consist of segmented dsRNA. These properties are evidence to distinguish RYEV from all plant virus groups described by Matthews ${ }^{12)}$. The only other viruses which have similar properties to those of RYEV are spinach temperate virus (STV), beet temperate virus (BTV), garland chrysanthemum temperate virus, rhubarb temperate virus, carrot temperate virus, alfalfa temperate virus (ATV) and white clover temperate virus (WCTV) ${ }^{14,16,17,18)}$ and "cryptic" viruses",6,7,10). Because of the lack of suitable infectivity test, of the very low concentration of virus in sap and of the symptomless infection, it is difficult to study the biological and physicochemical properties of "temperate" viruses and the serological relationships among them. Serological experiments have shown that RYEV clearly differs from all "temperate" viruses and beet cryptic virus. Furthermore, STV ${ }^{15)}, \mathrm{BTV}^{15)}, \mathrm{ATV}^{14)}$ and $\mathrm{WCTV}^{14)}$ have been revealed to contain segmented dsRNA. There are differences in molecular weight distribution of dsRNA among STV, BTV, ATV, WCTV and RYEV. Carnation cryptic virus also contain dsRNA ${ }^{9)}$. Because these seed-borne dsRNA viruses differ from all plant virus groups established ${ }^{12)}$, they can be grouped as a new type of plant viruses.

As for nucleic acid, it is known that reoviruses, bacteriophage $\phi 6$ and fungal viruses contain dsRNA genome ${ }^{12}$. Reoviruses and bacteriophage $\phi 6$ differ from RYEV in particle morphology and sizes of dsRNA. Although fungal viruses differ from RYEV in type of host, some of them are similar to RYEV in particle morphology, latent infection, sedimentation coefficient of virus particles, protein mol. wt. and sizes of dsRNA ${ }^{3,4)}$. It may be interesting to study on the relationships between RYEV and fungal viruses.

\section{Literature cited}

1. Dahlberg, A. E., Dingman, C. W. and Peacock, A. C. (1969). J. Mol. Biol. 41 : 139-147.

2. Francki, R. I. B. and Jackson, A. O. (1972). Virology 48: 275-277.

3. Ghabrial, S. A. (1980). Ann. Rev. Phytopath. 18: 441-461.

4. Hollings, M. (1979). In Fungal viruses (Molitoris, H. P. et al. eds.). Springer-Verlag, Berlin, Heidelberg, New York. pp. 165-175.

5. Kassanis, B., White, R. F. and Woods, R. D. (1977). Phytopath. Z. $90: 350-360$.

6. Kenten, R. H., Cockbain, A. J. and Woods, R. D. (1980). Rep. Rothamsted Exp. Stn. for 1979 : 176 .

7. Koenig, R. and Lesemann, D. E. (1980). Plant Dis. $64: 782-784$.

8. Laemmli, U. K. (1970). Nature 227: 680-685.

9. Lisa, V., Boccardo, G. and Milne, R. G. (1981). Virology 115: 410-413.

10. Lisa, V., Luisoni, E. and Milne, R. G. (1980). Ann. appl. Biol. 98: 431-437.

11. Loening, U. E. (1967). Biochem. J. $102: 251-257$.

12. Matthews, R. E. F. (1982). Intervirology $17: 1-199$.

13. Morris, T. and Dodds, J. A. (1979). Phytopathology 69 : 293-298.

14. Natsuaki, K. T., Natsuaki, T., Okuda, S., Teranaka, M., Yamashita, S. and Doi, Y. (1983). Ann. Phytopath. Soc. Japan 49: 132-133.

15. Natsuaki, T., Okuda, S., Teranaka, M., Yamashita, S. and Doi, Y. (1983). Ibid. 49: 82. 
16. Natsuaki, T., Yamashita, S., Doi, Y. and Yora, K. (1979). Ibid. $45: 84$.

17. Natsuaki, T., Yamashita, S., Doi, Y. and Yora, K. (1979). Ibid. 45: 313-320.

18. Natsuaki, T., Yamashita, S., Doi, Y. and Yora, K. (1981). Ibid. $47: 94$.

19. Reddy, D. V. R., Kimura, I. and Black, L. M. (1974). Virology 60 : 293-298.

20. Wood, H. A. and Bozarth, R. F. (1972). Ibid. $47: 604-609$.

\section{和文 摘 要}

$$
\begin{gathered}
\text { ダイコン葉縁黄化ウイルス一新グループの } \\
\text { 種子伝染性二本鎖 RNA ウイルス }
\end{gathered}
$$

夏秋知英・山下修一・土居養二・奥田誠一・寺中理明

ダイコン葉縁黄化ウイルス ( $\mathrm{RYEV})$ を $\mathrm{CsCl}$ 平衡密度勾配遠心分離により純化した。ウイルス粒子は $\mathrm{CsCl}$ 中で浮遊密度が約 $1.37 \mathrm{~g} / \mathrm{cm}^{3}$ のところに 1 本のバンドを形成した。 RYEV 純化試料は典型的な核タ ンパクの紫外線吸収を示し，その $A_{\max } / A_{\min }$ と $A_{260} / A_{280}$ の比はそれぞれ約 1.10 と 1.39であった。 RYEV はアブラナ科植物に感染する 4 種のウイルス (turnip crinkle virus, turnip rosette virus, カブモザイク ウイルスキュウリモザイクウイルス）および RYEV に似た粒子形態と生物学的性状を有する10種の種子 伝染性ウイルスと血清反応を示さなかった。 RYEV の純化試料から SDS-ポリアクリルアミド電気泳動によ り分子量約63,000 と61,000の 2 種のタンパクのバンドが得られた。 RYEV の核酸は高塩濃度下で RNase に 耐性で, poly (I)：poly(C) 抗血清と反応することから二本鎖 RNA であることが判明した。 RYEV の二本 鎖 RNA はポリアクリルアミド電気泳動で分子量が約 $1.30,1.25,1.21 \times 10^{6}$ の 3 本のメジャーバンドと, 同じく $1.14,1.09 \times 10^{6}$ の 2 本のマイナーバンドに分かれた。 RYEV とそれに類似する数種の種子伝染性二 本鎖 RNA ウイルスは新しい植物ウイルスグループを形成するものと考学られた。 